\section{Vulvar basal cell carcinoma: report of a case involving the mucosa and review of the literature}

\author{
Marie Caucanas, ${ }^{1}$ Gebhard Müller, ${ }^{2}$ \\ Olivier Vanhooteghem ${ }^{1}$ \\ 'Department of Dermatology, Sainte \\ Elisabeth Hospital, Namur; \\ 2Department of Anatomopathology, IPG, \\ Gosselies, Belgium
}

\begin{abstract}
We report the case of woman who presented a vulvar basal cell carcinoma (BCC) on the inner part of the labium majus, treated with local resection. Vulvar BCC is a rare cancer but can be long misdiagnosed due to a non-specific presentation. Though even rarer, BCC involving the mucosal side of the labium majus has to be considered in the differential diagnosis of the vulvar tumors. A complete excision with free margins is the treatment most recommended. Other recommendations include the early identification of aggressive subtypes, which carry a greater risk of recurrence and spreading potential as well as a long-term follow-up with exhaustive muco-cutaneous examination.
\end{abstract}

\section{Case Report}

A 57-year-old woman presented with an asymptomatic genital eroded mucosal lesion that she had noticed two years earlier (Figure 1). Physical examination showed a papillomatous lesion of $2.2 \mathrm{X} 1.5 \mathrm{~cm}$, located on the mucosal surface of the left labium majus. There was visible pigmentation and bleeding. Lymph nodes areas remained free. The patient's medical history was unremarkable. Differential diagnosis was to be made between pemphigus vegetans and tumors of the vulvar area. A resection-biopsy was performed under local anesthesia and revealed a basal cell carcinoma of compact, nodular and pigmented type, with erosion on surface. All margins of excision were free of disease. Follow-up to date showed no evidence of recurrent or metastatic carcinoma.

\section{Discussion}

Basal cell carcinoma (BCC) of the vulva represents 2-3\% of the vulvar cancers and less than $1 \%$ of all BCC. Out of around 250 cases published so far, only twenty cases of BCC of the clitoris, the labia minora or the medial non-hair bearing aspect of the labia majora have been described. ${ }^{1}$ Review of the literature shows that, considering other mucosas, four cases related to the buccal mucosa have been published. $^{2-5}$ To our knowledge, no case involving the glans is reported. In the literature, vulvar BCC is commonly reported to affect white women, mostly in the post-menopausal period ${ }^{6}$ though some cases affecting younger women have been described. ${ }^{1}$ Diagnosis is difficult as presentation and clinical manifestations are unspecific. As a result, the delay for diagnosis reaches 5 to 6 years on average. ${ }^{1}$ Complaints mostly range from the discovery of an asymptomatic labial lesion to the evaluation of pruritus, pain or bleeding. Clinical manifestations are diverse and do not usually suggest BCC, lacking characteristic pearly and telangectasic aspects. ${ }^{1}$ They are showing an exophytic, ulcerated, pedunculate, infiltrating, nodular or pigmented lesion, mostly located on the nonmucosal surface of the labia majora. ${ }^{7}$ Differential diagnosis has to be made between pemphigus vegetans and tumors of the vulva (Table 1). ${ }^{1,6,8-15}$ BCC of the vulva is not located on a surface exposed to UV and therefore other risk factors need to be determined. To date, there hasn't been any evidence of clearly identified risk factors, especially for BCC involving mucosa. Possible associations remain prior radiation therapy ${ }^{1,16}$ and previous trauma such as a burn or a scar. ${ }^{16}$ Common risk factors to cutaneous BCC have to be considered: Gorlin syndrome, ${ }^{17,18}$ chronic radiation, ${ }^{1,16,19}$ chronic arsenic exposure ${ }^{20}$, mutations in p5321, xeroderma pigmentosum. ${ }^{11}$ Immunosuppressive medication has been suggested. ${ }^{16} \mathrm{~A}$ few cases have been reported in association with preexisting lesion: lichen sclerosis et atrophicus, ${ }^{22}$ Paget's disease, ${ }^{23}$ multiple tumors of the follicular infundibulum. ${ }^{1}$

Biopsy of any suspect lesion is widely recommended. ${ }^{7,16,24}$ Once diagnosis is confirmed, conservative surgery is most indicated, with free margins resection. ${ }^{1,25-27}$ Some cases of relapses have been reported and are possibly due to inadequate margins. Local recurrence varies from $0-25 \%$ in published reports ${ }^{1}$ with an average of $10-20 \%{ }^{7}$ The aggressiveness and recurrence of BCC vary according to histological pattern. ${ }^{7}$ Tumors of the morphea-like (nodular, sclerosing), metatypical (basosquamous), adenocystic or infiltrative types are more aggressive, leading to a higher rate of recurrences. An aggressive BCC is associated with often deep local infiltration and occasional perineural extension. ${ }^{7}$ Several cases of metastazing BCC have been reported with an incidence of $0.0028-0.1 \%$ and with a mean time from initial presentation reaching 9 years. ${ }^{7}$ These cases raise a challenging differential diagnosis in which it can be difficult to distin-
Correspondence: Olivier Vanhooteghem, Department of Dermatology, Sainte Elisabeth Hospital, B - 5000, Namur, Belgium.

E-mail: ovanhooteghem@hotmail.com

Key words: vulvar basal cell carcinoma.

Received for publication: 3 August 2011. Accepted for publication: 31 August 2011

This work is licensed under a Creative Commons Attribution NonCommercial 3.0 License (CC BYNC 3.0).

(C) Copyright M. Caucanas, G. Müller and 0 . Vanhooteghem, 2011

Licensee PAGEPress, Italy

Dermatology Reports 2011; 3:e37

doi:10.4081/dr.2011.e37

guish BCC from adnexal tumors. Eventually, BCC may be associated with another vulvar tumor, such as melanoma or epidermoid carcinoma. ${ }^{1}$ Most reported associated cancer with BCC of the vulva is uterine neck cancer (UNC). ${ }^{1}$ Considering the role of HPV in the genesis of UNC, a few studies have assessed the presence of HPV in genital BCC on small

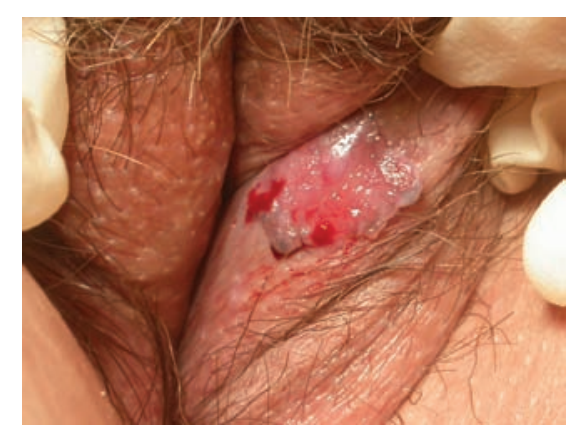

Figure 1. Eroded and pigmented papillomatous lesion located on the mucosal surface of the left labium majus.

Table 1. Vulvar cancers.

Squamous-cell cancers $90 \%$

Non-squamous tumors 10\%

Malignant melanoma

Bartholin's gland carcinoma

Verrucous carcinoma

Paget's disease

Adenosquamous carcinoma

Basal-cell carcinoma

Sarcoma

Leiomyosarcoma

Malignant fibrous histiocytoma

Dermatofibrosarcoma protuberans

Kaposi's sarcoma

Metastatic malignant disease

Lymphoma of the vulva

Merckel-cell cancer 
series of patients and with uneven results. ${ }^{1,28,29}$ Yet the implication of HPV in the BCC pathogenesis has not been proved. Most authors underline the fact that there is a possible significant morbidity and occasional mortality if a lesion such as BCC is neglected or improperly treated. $^{19}$

Considering the rates of relapse and possible aggressiveness of BCC, a close long-term follow-up is essential in order to decrease skin cancer morbidity through early detection and treatment. ${ }^{17}$

\section{References}

1. Mateus C, Fortier-Beaulieu M, Lhomme C, et al. Basal-cell carcinoma of the vulva: 21 cases. Ann Dermatol Venereol 2001;128: 11-5.

2. Del Rosario RN, Barr RJ, Jensen JL, Cantos KA. Basal cell carcinoma of the buccal mucosa. Am J Dermatopathol 2001; 23:203-5.

3. Samit AM. Intraoral basal cell carcinoma. J Surg Oncol 1978;10:27-32.

4. Keen RR, Elzay RP. Basal cell carcinoma from mucosal surface of lower lip: report of case. J Oral Surg Anesth Hosp Dent Serv 1964;22:453-5.

5. Liroff KP, Zeff S. Basal cell carcinoma of the palatal mucosa. J Oral Surg 1972;30: 730-3.

6. Finan MA, Barre G. Bartholin's gland carcinoma, malignant melanoma and other rare tumors of the vulva. Best Pract Res Clin Obstet Gynaecol 2003;17:609-33.

7. Pisani C, Poggiali S, De Padova L, et al. Basal cell carcinoma of the vulva. J Eur Acad Dermatol Venereol 2006;20:446-8.

8. Eliezri YD. The toluidine blue test: an aid in the diagnosis and treatment of early squamous cell carcinomas of mucous membranes. J Am Acad Dermatol 1988; 18:1339-49.

9. Lotem M, Anteby S, Peretz T, et al. Mucosal melanoma of the female genital tract is a multifocal disorder. Gynecol Oncol 2003; 88:45-50.

10. Wood WG, Giustini FG, Sohn S, Aranda RR. Verrucous carcinoma of the vagina. South Med J 1978;71:368-71.

11. Powell FC, Bjornsson J, Doyle JA, Cooper AJ. Genital Paget's disease and urinary tract malignancy. J Am Acad Dermatol 1985; 13:84-90.

12. Aartsen EJ, Albus-Lutter CE. Vulvar carcinoma: clinical implications. Eur J Obst Gynecol Reprod Biol 1994;56:181-9.

13. Giordano G, Gnetti L, Melpignano M. Endometrial carcinoma metastatic to the vulva : a case report and review of the literature. Pathol Res Pract 2005;201:751-6.

14. Iczkowski KA, Han AC, Edelson MI, Rosenblum NG. Primary, localized vulvar B-cell lymphoma expressing CD44 variant 6 but not cadherins. A case report. J Reprod Med 2000;45:853-6.

15. Waibel M, Richter K, Von Lengerken W, Niedobitek F. Merkel cell tumor (neuroendocrine carcinoma of the skin) in an unusual location. Immunohistochemical and lectin histochemical findings. Zentralbl Pathol 1991;137:140-50.

16. Gillian EG, Iftikhar A. Perianal and genital basal cell carcinoma: a clinicopathologic review of 51 cases. J Am Acad Dermatol 2001;45:68-71.

17. Perrone T, Twiggs LB, Adcock LL, Dehner LP. Vulvar basal cell carcinoma: an infrequently metastasizing neoplasm. Int $\mathrm{J}$ Gynecol Pathol 1987;6:152-65.

18. Giuliani M, Di Stefano L, Zoccali G, et al. Gorlin syndrome associated with basal cell carcinoma of the vulva: a case report. Eur J Gynaecol Oncol 2006;27:519-22.

19. Mulayim N, Foster Silver D, Tolgay Ocal I,
Babalola E. Vulvar basal cell carcinoma: two unusual presentations and review of the literature. Gynecol Oncol 2002;85:5327.

20. Cabrera HN, Cuda G, Lopez M, Costa JA. Basal cell epithelioma of the vulva in chronic endemic regional arsenic poisoning. Med Cutan Ibero Lat Am 1984;12:81-5.

21. Barrett TL, Smith KJ, Hodge JJ, et al. Immunohistochemical nuclear staining for p53, PCNA, and Ki-67 in different histologic variants of basal cell carcinoma. J Am Acad Dermatol 1997;37:430-7.

22. Meyrick Thomas RH, McGibbon DH, Munro DD. Basal cell carcinoma of the vulva in association with vulval lichen sclerosus et atrophicus. J R Soc Med 1985; 78 Suppl 11:16-8.

23. Ishizawa T, Mitsuhashi Y, Sugiki H, et al. Basal cell carcinoma within vulvar Paget's disease. Dermatology 1998;197:388-90.

24. de Giorgi V, Salvini C, Massi D, et al. Vulvar basal cell carcinoma: retrospective study and review of the literature. Gynecol Oncol 2005;97:192-4.

25. Ambrosini A, Becagli L, Resta P, et al. Basal cell carcinoma of the vulva. Eur J Gynaecol Oncol 1980;1:126-8.

26. Simonsen E, Johnsson JE, Tropé C, Alm P. Basal cell carcinoma of the vulva. Acta Obstet Gynecol Scand 1985;64:231-4.

27. Piura B, Rabinovitch A, Dgani R. Basal cell carcinoma of the vulva. J Surg Oncol 1999; 70:172-6.

28. Nehal KS, Levine VJ, Ashinoff R. Basal cell carcinoma of the genitalia. Dermatol Surg 1998;24:1361-3.

29. Santos M, Montagut C, Mellado B, et al. Immunohistochemical staining for p16 and p53 in premalignant and malignant epithelial lesions of the vulva. Int $\mathrm{J}$ Gynecol Pathol 2004;23:206-14. 